\title{
Penggunaan Media 3D SketchUp pada Pembelajaran Dimensi Tiga untuk Meningkatkan Kemampuan Spatial Sense pada Siswa Kelas XII IPA SMAN 1 Kota Sukabumi
}

\author{
Ani Riani Sekarwulan ${ }^{(1)}$ \\ ${ }^{1}$ SMA Negeri 1 Kota Sukabumi \\ Email: ${ }^{1}$ anirianisekarwulan@gmail.com \\ DOI:http://doi.org/10.28926/riset_konseptual.v2i4.121
}

\begin{abstract}
ABSTRAK
Penelitian ini bertujuan untuk mengetahui kondisi objektif tentang peningkatan kemampuan spatial sense siswa XII IPA SMA Negeri 1 Kota Sukabumi dan respon siswa terhadap pembelajaran menggunakan media 3D SketchUp. Kemampuan spatial sense siswa dilihat dari proses menyelesaikan persoalan matematika pada pembelajaran dimensi tiga dengan menggunakan 3D SketchUp sebagai media pembelajaran. Penggunaan pembelajaran menggunakan media 3D SketchUp dengan desain penelitian tindakan kelas mampu meningkatkan kemampuan spatial sense siswa pada pembelajaran dimensi tiga kelas XII IPA SMA Negeri 1 Kota Sukabumi. Hal ini terbukti dengan perolehan rata-rata hasil tes siswa pada tiap siklus relatif terjadi kenaikan. Hasil siklus I rata-rata spatial sense siswa adalah $72 \%$, hasil siklus II rata-rata spatial sense siswa adalah $74 \%$, hasil siklus III rata-rata spatial sense siswa adalah $78 \%$, dan hasil siklus IV rata-rata spatial sense siswa adalah $87 \%$. Hasil tes pada siklus I dan pada tes formatif mengalami peningkatan. Data ini mengindikasikan bahwa siswa mengalami peningkatan kemampuan spatial sense. Sikap siswa terhadap pelajaran matematika secara keseluruhan menunjukkan sebagian besar bersikap positif (84\%).
\end{abstract}

Kata kunci: spatial sense, 3D SketchUp

\section{PENDAHULUAN}

Pembelajaran matematika merupakan salah satu komponen pendidikan mempunyai peranan sangat penting bagi kualitas sumber daya manusia yang mampu bertindak atas dasar pemikiran matematis yaitu logis, rasional, kritis, dan sistematis guna membantu permasalahan sehari-hari atau dalam mempelajari ilmu yang lain. Geometri merupakan salah satu cabang matematika yang dekat dengan lingkungan. Bahkan, bentuk-bentuk geometri sudah dikenal dan mudah ditemukan di dalam kehidupan sehari-hari.

Walle (dalam Sujadi R, 1999) mengungkapkan lima alasan mengapa geometri sangat penting untuk dipelajari, yaitu: (1) geometri membantu manusia memiliki apresiasi yang utuh tentang dunianya, dijumpai dalam sistem tata surya, formasi geologi, kristal, tumbuhan dan binatang, karya seni arsitektur, dan hasil kerja mesin; (2) eksplorasi geometri dapat membantu mengembangkan ketrampilan pemecahan masalah; (3) geometri memainkan peranan utama dalam bidang matematika lainnya; (4) geometri digunakan oleh banyak orang dalam kehidupan sehari-hari; dan (5) geometri penuh dengan tantangan dan menarik.

Pembelajaran geometri erat kaitannya dengan spatial sense. Sodikin (2013) mendefinisikan spatial sense sebagai suatu jenis penalaran yang didasarkan pada penggunaan imajinasi. Menurut M. Muklas (2016), spatial sense adalah keterampilan dalam merepresentasikan, mentransformasi, membangun, dan memanggil kembali informasi simbolik tidak dalam bentuk bahasa. Sedangkan Linn dan Peterson (dalam Yuliardi, 2010: 28) mendefinisikan spatial sense sebagai proses mental yang 
JURNAL PENDIDIKAN: Riset dan Konseptual, Vol. 3 No. 2, April 2019 www.journal.unublitar.ac.id/jp

E-ISSN: 2598-2877,

P-ISSN: 2598-5175

digunakan untuk menerima, menceritakan, memanggil kembali, membuat, menyusun, dan membuat hubungan objek ruang. Mengacu pada uraian di atas, spatial sense adalah kemampuan dalam membayangkan, menelaah, dan menganalisis ruang.

Pada kenyataannya masih banyak siswa yang beranggapan bahwa geometri merupakan pelajaran yang sulit. Berdasarkan hasil belajar siswa pada tahun sebelumnya, pemahaman untuk bidang geometri masih kurang dan pada prosesnya banyak siswa yang tidak bisa "membayangkan kondisi tiga dimensi" yang artinya banyak siswa yang tidak bisa membayangkan kondisi tiga dimensi yang tergambar pada papan tulis atau kertas. Hal ini terlihat dari pengerjaan siswa pada hasil tes pokok bahasan dimensi tiga pada tahun sebelumnya, siswa lebih kesulitan pada saat mengerjakan soal yang membutuhkan High Order Thinking Skills (HOTS). Oleh karena itu, diperlukan media pembelajaran yang dapat membantu siswa dalam membayangkan kondisi tiga dimensi.

Teknologi berkembang dengan pesat sehingga teknologi dapat digunakan untuk membantu dalam pembelajaran matematika, khususnya pada materi-materi yang tidak mudah untuk diajarkan oleh alat bantu biasa. Pembelajaran Matematika untuk Geometri dibutuhan suatu media yang dapat menampilkan pesan secara visual, audio, dan bahkan audio visual. Teknologi terus berkembang dan banyak produk rekayasa komputer atau aplikasi yang diciptakan.

Menurut M. Mukhlas (2016), penggunaan perangkat lunak (software) komputer sebagai media / alat bantu pada kegiatan pembelajaran sangat banyak , beberapa perangkat lunak (software) komputer dapat membuat bangun-bangun geometri, melatih kemampuan membayangkan dan menelaah ruang (spatial sense), sekaligus melatih menganalis ruang atau melatih kemampuan pemecahan masalah. 3D SketchUp merupakan salah satu dari sekian banyak perangkat lunak (software) komputer yang berfungsi untuk membuat gambar tiga dimensi. SketchUp didesain dengan sangat familiar dan mudah digunakan oleh siapapun tanpa harus menguasai teknik-teknik yang rumit.

Penelitian ini dibatasi pada materi geometri dimensi tiga yang meliputi konsep titik, jarak, serta sudut garis dan bidang pada kubus, balok, prisma, dan limas. Tujuan dari penelitian ini adalah untuk mengetahui ada tidaknya peningkatan kemampuan spatial sense pada siswa yang belajar dengan menggunakan media 3D SketchUp serta untuk mengetahui sikap siswa terhadap pembelajaran dimensi tiga menggunakan media 3D SketchUp.

\section{METODE}

Metode yang digunakan pada penelitian ini adalah metode tindakan kelas karena penelitian bertujuan untuk mengetahui apakah sekelompok siswa yang mendapatkan pembelajaran dengan menggunakan media 3D SketchUp mengalami peningkatan spatial sense. Adapun yang menjadi subjek penelitian ini adalah siswa kelas XII IPA Program 4 Semester di SMA Negeri 1 Kota Sukabumi yang berjumlah 36 siswa.

Model dan pendekatan yang digunakan adalah model yang dianjurkan di kurikulum 2013 yaitu Problem Based Learning (PBL). Pendekatan ini diterapkan untuk siswa kelas XII IPA Program 4 Semester SMA Negeri 1 Kota Sukabumi. Siswa pada kelas ini adalah siswa yang memiliki motivasi belajar yang baik sehingga materi geometri dapat dipahami lebih mendalam dengan menggunakan bantuan media 3D SketchUp dan model pembelajaran Problem Based Learning (PBL) sehingga diharapkan siswa bisa lebih menguasai soal-soal HOTS

Peneliti berperan sebagai guru yang melakukan pengajaran dengan menerapkan pendekatan Problem Based Learning (PBL) dan menggunakan media 3D SketchUp. Guru matematika turut hadir untuk berperan sebagai pengamat (observer) selama pembelajaran berlangsung.

Pada penelitian ini ada 4 siklus, setiap siklus terdiri dari 2 pertemuan, karena disesuaikan dengan materi dimensi tiga kelas XII IPA. Pada setiap siklusnya terdiri dari 
JURNAL PENDIDIKAN: Riset dan Konseptual, Vol. 3 No. 2, April 2019 www.journal.unublitar.ac.id/jp

E-ISSN: 2598-2877,

P-ISSN: 2598-5175

perencanaan (planning), tindakan (acting), dan observasi (observing) dari tindakan yang dilakukan serta refleksi (reflecting) atas tindakan yang dilakukan. Jika pada siklus pertama pembelajaran dirasakan kurang baik, maka dilakukan perbaikan rencana yang telah dibuat untuk pembelajaran selanjutnya. Instrumen yang digunakan dalam penelitian ini adalah tes uraian dan angket.

Tes uraian dilakukan untuk mengetahui sejauh mana kemampuan spatial sense siswa. Tes yang diberikan berupa tes siklus dan tes formatif. Tes formatif diberikan setelah semua siklus dilakukan. Tes dilakukan bertujuan untuk menganalisis peningkatan kemampuan spatial sense siswa dan ketuntasan belajar siswa terhadap seluruh materi yang telah diberikan pada semua siklus.

Tes diberikan secara tertulis berbentuk uraian karena berkaitan dengan hasil belajar berkategori tingkat tinggi yaitu kemampuan spatial sense siswa. Hal ini sesuai dengan apa yang dikemukakan oleh Eko Suprianto (2012) yang menyatakan bahwa tes berbentuk uraian sangat cocok untuk mengukur higher level learning outcomes.

Kemampuan Spatial sense siswa kelas XII IPA Program 4 semester pada pembelajaran Dimensi Tiga dengan menggunakan Media 3D SketchUp Indikator keberhasilan dapat dilihat dari hasil nilai tes, yaitu :

presentasi kemampuan spatial sense $=$ (jumlah skor perolehan siswa:jumlah skor maksimal indikator) $\times 100 \%$.

Dengan klasifikasi:

$80 \%<\mathrm{NR} \leq 100 \%$ Sangat baik

$60 \%<\mathrm{NR} \leq 80 \% \quad$ Baik

$40 \%<\mathrm{NR} \leq 60 \% \quad$ Cukup Baik

$20 \%<\mathrm{NR} \leq 40 \% \quad$ Kurang baik

$0 \%<\mathrm{NR} \leq 20 \% \quad$ Tidak baik (Arikunto, 2002)

Ketuntasan belajar (kemampuan Spatial Sense) berdasarkan kurikulum akan dicapai jika seorang siswa memperoleh skor hasil belajar lebih dari atau sama dengan $75 \%$ dari skor maksimum, sedangkan untuk ketuntasan belajar klasikal akan diperoleh jika terdapat lebih dari atau sama dengan $85 \%$ siswa di kelas tersebut yang memperoleh skor hasil belajar lebih dari atau sama dengan $75 \%$.

Pada penelitian ini digunakan angket, untuk mengetahui sikap siswa terhadap pembelajaran yang telah dilaksanakan, serta untuk mengetahui bagaimana kemampuan spatial sense siswa setelah melaksanakan pembelajaran matematika. Angket dibagikan setelah tes formatif dilakukan. Pengumpulan data yang didasarkan pada hasil penilaian secara obyektif memerlukan sistem penskoran yang proporsional untuk tiap soal atau pertanyaan dari kedua instrumen penelitian, baik tes uraian maupun angket.

\section{HASIL}

Hasil dari penelitian tindakan kelas ini diperoleh dari data-data yaitu hasil; tes siklus dan formatif yang bertujuan untuk menganalisis Spatial Sense. Selain data hasil tes, diperoleh juga data-data hasil observasi sebagai deskripsi aktivitas siswa pada saat pembelajaran. Hasil observasi ini merupakan bahan refleksi untuk memperbaki dan meningkatkan pembelajaran di kelas. Selain hasil observasi diperoleh juga hasil data hasil angket siswa sebagai pernyataan sikap siswa terhadap pembelajaran.

Data dianalisis dan didapat Pembelajaran menggunakan media 3D SketchUp mampu meningkatkan kemampuan spatial sense siswa pada pembelajaran dimensi tiga kelas XII IPA SMA Negeri 1 Kota Sukabumi. Hal ini terbukti dengan perolehan rata-rata hasil tes siswa pada tiap siklus relatif terjadi kenaikan. Hasil siklus I rata-rata spatial sense siswa adalah $72 \%$, hasil siklus II rata-rata spatial sense siswa adalah $74 \%$, hasil siklus III rata-rata spatial sense siswa adalah $78 \%$, dan hasil siklus IV ratarata spatial sense siswa adalah $78 \%$. Hasil tes pada siklus I dan pada tes formatif mengalami peningkatan. Data ini mengindikasikan bahwa siswa mengalami 
JURNAL PENDIDIKAN: Riset dan Konseptual, Vol. 3 No. 2, April 2019 www.journal.unublitar.ac.id/jp

E-ISSN: 2598-2877,

P-ISSN: 2598-5175

peningkatan kemampuan spatial sense. Sikap siswa terhadap pelajaran matematika secara keseluruhan menunjukkan sebagian besar bersikap positif (84\%).

\section{PEMBAHASAN}

Penelitian ini meliputi beberapa faktor yaitu pendekatan pembelajaran menggunakan media 3D SketchUp, kemampuan spatial sense siswa dan sikap siswa. Untuk membahas hasil penelitian lebih lanjut, dilakukan pembahasan berdasarkan ketiga faktor tersebut di atas.

Pembahasan hasil penelitian berkaitan dengan pendekatan pembelajaran dapat dilihat dari Pembelajaran dengan pendekatan Problem Based Learning, Siswa dikondisikan untuk melakukan observasi sebelum membuat kesimpulan, diharapkan siswa akan memperoleh pembelajaran matematika secara bermakna. Contohnya, konsep sudut antara garis dan Bidang, siswa telah memahami tentang Rumus-rumus Trigonometri seperti perbandingan Trigonometri, Luas segitiga dan aturan cosinus pada pembahasan sebelumnya.

Pendekatan pembelajaran yang biasa digunakan oleh guru juga sangat berpengaruh terhadap kebiasaan atau cara belajar siswa. Beberapa siswa kesulitan mengikuti pembelajaran dengan pendekatan Problem Based Learning, terutama dalam mengasosiasi informasi dan mengkomunikasikannya. Hal ini disebabkan siswa belum terbiasa untuk belajar mandiri, belum terbiasa mengumpulkan informasi dan mengolahnya sendiri.

Pembelajaran menggunakan media $3 D$ SketchUp membuat suasana di kelas menjadi berbeda, siswa menjadi lebih termotivasi dan tertarik karena dipermudah dengan adanya bantuan gambar bangun ruang yang menyerupai aslinya yang dibisa diputar-putar sesuai kebutuhan sehingga bisa dilihat dari berbagai sudut. Berbeda kalau siswa melihat gambar bangun ruang dari papan tulis atau kertas (dua dimensi). Media 3D SketchUp juga mengeksplore potensi kemampuan analisis ruang siswa, sehingga soal-soal HOTS yang diberikan bisa diselesaikan. Penggunaan Media 3D SketchUp dengan pendekatan PBL sangat efektif agar siswa belajar secara bermakna dan melatih kemampuan spatial sense siswa dengan lebih optimal, karena obyek matematika yang abstrak membutuhkan pemahaman melalui observasi oleh siswa sendiri. Dengan dikuasainya suatu konsep secara lebih mendalam maka siswa akan lebih mudah memahami bahan ajar selanjutnya karena karakteristik pengertian/konsep atau pernyataan/sifat pada mata pelajaran matematika yang sangat jelas berjenjang, membutuhkan penguasaan konsep sebagai penunjang pada bahan ajar selanjutnya.

\section{Siklus I}

Materi yang diberikan masih konsep dasar mengenai titik, garis dan bidang. Setelah pembelajaran berakhir guru berdiskusi dengan pengamat/observer mengenai proses pembelajaran yang terjadi. Menurut catatan pengamat, waktu yang diberikan untuk siswa dalam menyelesaikan masalah menggunakan bantuan SketchUp masih kurang. Hal ini memang dirasakan sekali oleh peneliti, peneliti merasa bahwa apa yang direncanakan harus terlaksana dengan baik sehingga tempo pembelajaran dipercepat. Sedangkan beberapa siswa daya abstraksinya masih kurang. Sehingga masih kesulitan, tetapi dengan bantuan SketchUp siswa tertolong, hanya waktu penggunaan sketchUp masih agak lambat dikarenakan belum terbiasa penggunaannya.

Siswa mengikuti proses pembelajaran dengan tertib. Hanya masih ada siswa yang kesulitan dalam memahami pembelajaran. Dan ada kelompok yang masih lambat menggunakan SketchUp. Motivasi belajar siswa baik dan memperhatikan penjelasan guru dengan seksama dan ini menunjukkan hal positif. Secara keseluruhan siswa dapat megikuti pembelajaran dengan tertib dan lancar tanpa hambatan yang cukup berarti.

Dari data hasil tes siklus I yang diperoleh tersebut diketahui bahwa hanya 29 orang siswa yang dikategorikan tuntas belajar atau $81 \%$ siswa dinyatakan tuntas belajar 
JURNAL PENDIDIKAN: Riset dan Konseptual, Vol. 3 No. 2, April 2019 www.journal.unublitar.ac.id/jp

E-ISSN: 2598-2877,

P-ISSN: 2598-5175

sedangkan $11 \%$ lainnya belum tuntas. Siswa yang masuk dalam kualifikasi Spatial Sense sangat baik terdapat 39\% sedangkan $44 \%$ lainnya dinyatakan pada kualifikasi Spatial Sense Baik. Sekitar 17\% masuk dalam kualifikasi Spatial Sense cukup baik , sedangkan $0 \%$ dinyatakan pada kualifikasi Spatial Sense kurang dan $0 \%$ berkualifikasi Spatial Sense buruk.

\section{Siklus II}

Materi yang diberikan kedudukan titik, garis dan bidang Setelah pembelajaran berakhir guru berdiskusi dengan pengamat mengenai proses pembelajaran yang terjadi. Menurut catatan pengamat, guru dalam mengajar sudah lebih baik sehingga tidak terburu-buru dalam mengejar target pembelajaran. Secara umum pembelajaran yang dilaksanakan oleh guru pada hari itu sudah sesuai dengan rencana.

Siswa mengikuti proses pembelajaran dengan tertib. Dalam diskusi kelas pada pembelajaran siklus II ini, diskusi dalam kelas semakin baik, namun masih ada siswa yang belum memahami dengan baik. Diskusi kelompok berjalan baik walaupun ada beberapa siswa yang belum terlihat aktif, tapi dimotivasi oleh teman kelompoknya untuk terlibat aktif.

Data yang diperoleh dari hasil tes Siklus II bahwa 86\% siswa dinyatakan tuntas belajar sedangkan $14 \%$ lainya belum tuntas. Siswa yang masuk dalam kualifikasi Spatial Sense Sangat Baik adalah $42 \%$ sedangkan siswa yang dinyatakan pada kualifikasi Spatial Sense Baik adalah $42 \%$, sekitar 14\% masuk dalam kualifikasi Spatial Sense Cukup baik, dan 2\% masuk dalam kualifikasi Spatial Sense kurang. Data tersebut mengindikasikan bahwa tingkat ketuntasan belajar mengalami kenaikan disbanding siklus I, Spatial Sense siswa sudah meningkat bila dibandingkan dengan Penelitian Siklus I, hanya ada 1 siswa mengalami penurunan kriteria Spatial sense dari cukup ke kurang, ini disebabkan materi Siklus II kompleksitasnya lebih tinggi dikarenakan selain harus menggambarkan juga harus menghitung menggunakan konsep - konsep lain.

\section{Siklus III}

Materi yang diberikan jarak antara titik, garis dan bidang. Setelah pembelajaran berakhir guru berdiskusi dengan pengamat mengenai proses pembelajaran yang terjadi. Menurut catatan pengamat, secara umum pembelajaran yang dilaksanakan oleh guru pada hari itu sudah sesuai dengan rencana.

Siswa mengikuti proses pembelajaran dengan tertib. Dalam diskusi kelas pada pembelajaran siklus III ini, diskusi dalam kelas semakin baik, namun masih ada siswa yang belum memahami dengan baik. Diskusi kelompok berjalan baik walaupun ada beberapa siswa yang belum terlihat aktif, tapi dimotivasi oleh teman kelompoknya untuk terlibat aktif.

Siswa juga memperhatikan penjelasan guru dengan seksama dan ini menunjukan hal positif bagi kelangsungan pembelajaran ini. Secara keseluruhan siswa dapat mengikuti pembelajaran, berdasarkan pengamatan observer

Dari data hasil tes siklus III yang diperoleh diketahui bahwa $83 \%$ siswa dinyatakan tuntas belajar sedangkan $17 \%$ lainya belum tuntas. Siswa yang masuk dalam kualifikasi Spatial Sense Sangat Baik adalah 33\% sedangkan siswa yang dinyatakan pada kualifikasi Spatial Sense Baik adalah 50\%, sekitar 17\% masuk dalam kualifikasi Spatial Sense Cukup, Data tersebut mengindikasikan bahwa tingkat ketuntasan belajar mengalami penurunan disbanding siklus II, tetapi Spatial Sense siswa meningkat bila dibandingkan dengan hasil pada Siklus I, siswa mengalami penurunan kriteria Spatial sense ini disebabkan materi Siklus II kompleksitasnya lebih tinggi dikarenakan selain harus menggambarkan juga harus menghitung menggunakan konsep - konsep lain.

\section{Siklus IV}

Materi yang diberikan adalah sudut antara 2 garis, garis dan bidang, dan antara 2 bidang. Setelah pembelajaran berakhir guru berdiskusi dengan pengamat 
JURNAL PENDIDIKAN: Riset dan Konseptual, Vol. 3 No. 2, April 2019 www.journal.unublitar.ac.id/jp

E-ISSN: 2598-2877,

P-ISSN: 2598-5175

mengenai proses pembelajaran yang terjadi. Menurut catatan pengamat, secara umum pembelajaran yang dilaksanakan oleh guru pada hari itu sudah sesuai dengan rencana.

Siswa mengikuti proses pembelajaran dengan tertib. Dalam diskusi kelas pada pembelajaran siklus IV ini, diskusi dalam kelas semakin baik, namun masih ada siswa yang belum memahami dengan baik. Diskusi kelompok berjalan baik walaupun ada beberapa siswa yang belum terlihat aktif, tapi dimotivasi oleh teman kelompoknya untuk terlibat aktif. Secara keseluruhan siswa dapat mengikuti pembelajaran, berdasarkan pengamatan observer.

Peneliti menilai siswa masih ragu-ragu dalam mengemukakan pendapatnya pada pertemuan pertama ini. Hal ini dikarenakan materi sudut antara garis dan bidang lebih sulit dan tingkat kompleksitasnya tinggi, karena berhubungan dengan konsep lain yaitu Trigonometri. Kemudian setelah selesai membahas soal yang ada pada LKS, guru membimbing siswa untuk merangkum materi pelajaran yang telah didapatkan pada pembelajaran siklus III ini lalu siswa mengisi lembar angket pembelajaran yang telah disediakan.

Dari data hasil tes siklus III yang diperoleh diketahui bahwa $80 \%$ siswa dinyatakan tuntas belajar sedangkan $20 \%$ lainya belum tuntas. Siswa yang masuk dalam kualifikasi Spatial Sense Sangat Baik adalah 36\% sedangkan siswa yang dinyatakan pada kualifikasi Spatial Sense Baik adalah 47\%, sekitar 17\% masuk dalam kualifikasi Spatial Sense Cukup, Data tersebut mengindikasikan bahwa tingkat ketuntasan belajar mengalami sedikit penurunan dibanding siklus III, tetapi Spatial Sense siswa meningkat bila dibandingkan dengan hasil pada Siklus I, siswa mengalami penurunan kriteria Spatial sense ini disebabkan materi Siklus IV kompleksitasnya lebih tinggi dikarenakan selain harus menggambarkan juga harus menghitung menggunakan konsep lain yaitu Trigonometri.

\section{Ketuntasan Belajar}

Ketuntasan belajar (kemampuan Spatial Sense) berdasarkan kurikulum akan dicapai jika seorang siswa memperoleh skor hasil belajar lebih dari atau sama dengan $75 \%$ dari skor maksimum, sedangkan untuk ketuntasan belajar klasikal akan diperoleh jika terdapat lebih dari atau sama dengan $85 \%$ siswa di kelas tersebut yang memperoleh skor hasil belajar lebih dari atau sama dengan $75 \%$. Berdasarkan hasil tes formatif didapat bahwa untuk kemampuan Spatial Sense, dari 36 siswa terdapat 31 siswa tuntas dan 5 siswa tidak tuntas, artinya siswa yang dikategorikan tuntas belajar $86 \%$ siswa dinyatakan tuntas belajar sedangkan $14 \%$ lainnya belum tuntas. Dengan demikian sudah tercapai ketuntasan klasikal.

\section{Sikap Siswa}

Sikap siswa terhadap pembelajaran matematika menggunakan SketchUp dan soalsoal kemampuan Spatial Sense menunjukkan sebagian besar siswa bersikap positif. $\mathrm{Hal}$ ini ditunjukkan pada semua kegiatan pembelajaran di kelas mereka bersungguhsungguh dalam memahami pelajaran (konsep), menyelesaikan tugas dengan baik, berpartisipasi aktif dalam diskusi, merespon tantangan yang datang dari pelajaran matematika, dan mengerjakan tugas-tugas rumah dengan tuntas dan tepat waktu.

Hasil penelitian menunjukkan bahwa penerapan metode pembelajaran dimensi tiga menggunakan SketchUp dengan pendekatan Problem Based Learning mampu meningkatkan spatial sense siswa kelas XII IPA Program 4 Semester SMA Negeri 1 Kota Sukabumi.

\section{KESIMPULAN}

Berdasarkan hasil penelitian dapat disimpulkan bahwa penerapan metode pembelajaran dimensi tiga menggunakan media 3D SketchUp mampu meningkatkan spatial sense siswa kelas XII IPA Program 4 Semester SMA Negeri 1 Kota Sukabumi. 
JURNAL PENDIDIKAN: Riset dan Konseptual, Vol. 3 No. 2, April 2019 www.journal.unublitar.ac.id/jp

E-ISSN: 2598-2877,

P-ISSN: 2598-5175

Hal ini terbukti dengan adanya peningkatan perolehan rata-rata hasil tes siswa pada tiap siklus. Hasil tes evaluasi tuntas secara klasikal. Data perbandingan antara hasil tes siklus I dan tes evaluasi terlihat mengalami peningkatan yang signifikan. Hal ini mengindikasikan bahwa siswa mengalami peningkatan kemampuan spatial sense. Respon terhadap pembelajaran dimensi tiga dengan menggunakan SketchUp dan pendekatan Problem Based Learning pada siswa kelas XII IPA Program 4 Semester SMA Negeri 1 Kota Sukabumi Tahun Ajaran 2017/2018 sangat baik dan positif. Hal ini terlihat dari respon positif pada hasil penilaian sikap siswa melalui hasil observasi dan angket.

\section{SARAN}

Pembelajaran menggunakan media $3 D$ SketchUp dengan pendekatan Problem Based Learning dapat dijadikan sebagai referensi metode pembelajaran untuk meningkatkan spatial sense siswa. Alangkah baiknya sebelum pembelajaran, Siswa dikondisikan sudah dapat mengoperasikan aplikasi 3D SketchUp, dan selama pembelajaran setiap kelompok siswa memegang sebuah computer atau laptop agar siswa lebih focus berdikusi menyelesaikan permasalahan berbantuan $3 D$ SketchUp dengan cara menggambar sendiri bangun ruang sesuai permasalahan yang diberikan tanpa harus mengandalkan gambar yang ditampilkan oleh guru. Aplikasi 3D SketchUp sangat mengasyikan apalagi untuk siswa yang memiliki kemmpuan IT yang tinggi, hal ini siswa kadang tidak bisa mengatur waktu karena keasyikan membuat gambar bangun ruang, peran Guru dibutuhkan untuk memandu kegiatan agar pembelajaran selesai sesuai waktunya. Solusi lain, untuk efektivitas waktu, siswa ditugaskan dirumah untuk membuat gambar-gambar bangun ruang yang dibutuhkan untuk pertemuan selanjutnya.

\section{DAFTAR RUJUKAN}

Arikunto, S. dkk. 2006. Penelitian Tindakan Kelas. Jakarta, Bumi Aksara.

Eko Suprianto, 2012. Pengembangan Kurikulum Pendidikan Cerdas Istimewa. Jogjakarta: Pustaka Pelajar

Hamalik, Oemar. 1980. Media Pendidikan. Bandung: Alumni.

Komalasari, Kokom. 2010. Pembelajaran Kontektual Konsep dan Aplikasi. Bandung: Refika Aditama.

M. Mukhlas, S.E dan M. Thoyyib, 2015. Teknologi Informasi Berbasis Informasi. Surabaya: Indah Surabaya

Nasution, S. 1995. Didaktik Azas-Azas Mengajar. Jakarta: Bumi Aksara.

Radyastuti, W. dkk. 2000. Pedoman Pelaksanaan Tindakan Kelas. Malang: Lembaga Ilmu Pengetahuan Indonesia, Badan Pengkajian Penerapan Teknologi.

Sodikin. 2013. Pembelajaran Matematika Realistik Pokok Bahasan Geometri Surabaya: Tesis PPs Unesa.

Soedjadi, R. 1999. Kiat Pendidikan Matematika di Indonesia. Jakarta: Dirjen Dikti, Depdikbud.

Somerset, A. 1997. Strengthening Quality in Indonesia's Junior Secondary School on Overvies Issues Initiatives. Jakarta: MOEC.

Sudjana, N. 2004. Penelitian dan Penilaian Pendidikan. Bandung: Sinar Baru Algensindo.

Wena, Made. 2009. Strategi Pembelajaran Inovatif Kontemporer. Jakarta: Bumi Aksara.

Wiriaatmadja, R. 2005. Metode Penelitian Tindakan Kelas. Bandung: Remaja Rosdakarya. 